\title{
Modeling of Benzene with Ethylene Alkylation
}

\author{
Elena Khlebnikova ${ }^{1,}$, , Irena Dolganova ${ }^{1}$, Elena Ivashkina ${ }^{1}$, Stanislav Koshkin ${ }^{1,2}$ \\ ${ }^{1}$ Tomsk Polytechnic University, Tomsk, Russia \\ ${ }^{2}$ LLC NIOST, Tomsk, Russia
}

\begin{abstract}
The paper considers the benzene alkylation with ethylene model development with the use of zeolite catalyst. A list of reactions occurring in the alkylation reactor was made and the thermodynamic possibility of determination of these reactions by the change of Gibbs energy was defined. The paper presents the hydrocarbons transformation scheme, which includes the grouping of components on the basis of their reactivity and the degrees of compensation values of the corresponding reactions. Drawing on the obtained data the authors developed the kinetic model of the alkylation of benzene with ethylene.
\end{abstract}

\section{Introduction}

Since the 70 s of the last century it became possible to produce ethylbenzene with the use of heterogeneous zeolite catalyst on a commercial scale. Heterogeneous catalytic process gradually started to replace the old homogeneous catalytic technology. Nowadays most of the existing ethylbenzene production plants operate using the zeolite catalyst $[1,2]$. According to the data of 2014 total world ethylbenzene production capacity is around 37 millions tons per year [3].

Technology of ethylbenzene production includes the stages of alkylation and transalkylation. The control of technological parameters such as benzene-to-ethylene ratio in the feed and temperature lets to conduct the process under the optimum conditions and monitor the output of ethylbenzene $[4,5]$.

Although the technology developers provide their recommendations on the values of these parameters, the development of the model of ethylbenzene synthesis process and its subsequent modeling aimed at the increase of the resource and energy efficiency of the production plant is one of the most feasible ways of customization of the process to particular cases [6].

\section{Object of the research}

The ethylbenzene technology is developed for ethylbenzene production with the use of the liquid phase and zeolite catalyst.

The industrial plant operates continuously and uses 2 different reactors for alkylation and transalkyation.

In alkylation reactor ethylene in its liquid phase goes through almost a complete reaction accompanied by the excess of benzene, which is necessary to form ethylbenzene (EB):

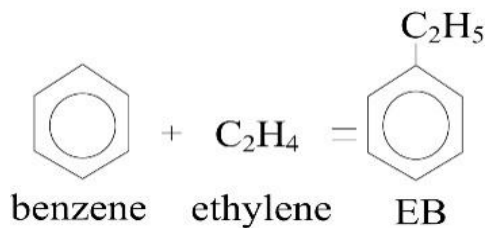

The process takes place at $\mathrm{T}=220-255{ }^{\circ} \mathrm{C}$ and $\mathrm{P}=3.4 \mathrm{MPa}$. This reaction is exothermic, which leads to gradual temperature increase from one catalyst bed to the following one. This is the reason why alkylation reactors are typically equipped with intermediate coolers for keeping the total temperature rise.

Then ethylbenzene converts to produce small amounts of polyethylbenzenes (PEB):

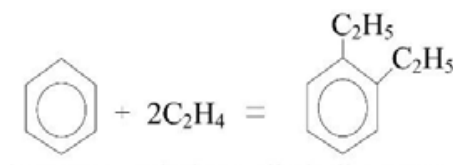

benzene ethylene diethylbenzene<smiles>CCc1cccc(CC)c1CC</smiles>

benzene ethylene triethylbenzene

These reactions are the main side ones and generate considerable quantities of heat being exothermic ones.

PEB are separated from ethylbenzene and then converted to $\mathrm{EB}$ in the transalkyation reactor at $\mathrm{T}=190$ $220^{\circ} \mathrm{C}$ and $\mathrm{P}=3-3.5 \mathrm{MPa}$.

By now the chemistry of ethylbenzene synthesis is quite well understood $[7,8]$. In addition to the main reactions leading to ethylbenzene formation it's known a number of side reactions. Altogether these reactions are a challenging task from the perspective of mathematical description and its subsequent use. Representation and adequacy of a mathematical model and its ability to be

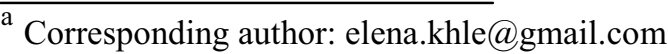


approximate enough to the real data depend on reaction scheme of the model. This scheme should be quite simple, but at the same time accurate enough to describe the process [9].

\section{Model development}

Reactions that occur in alkylation and transalkyation processes and that are based on different types of the zeolite catalyst were investigated by certain authors [1012]. However, alkylation and transalkyation have different conversion processes schemes, and at the same time they have quite much in common. So the main task is to determine the pathway of the development of secondary reactions: transalkyation, disproportionation, dealkylation, cracking and other ones, the result of which is the formation of by-products. Some steps were taken to make up a detailed reaction scheme based on industrial data and the existing knowledge about the process [13]. We offer the method of designing of the math model that combines industrial data, research results and quantumchemical calculation.

The list of possible reactions for benzene alkylation was made with account of the quality of sources (ethylene and benzene), product composition and aspects of the process chemistry.

Thermodynamic possibility of these reactions has been confirmed by determination of the isobaricisothermal parameter - the change of Gibbs energy $\Delta G$ at $\mathrm{T}=510^{\circ} \mathrm{K}$ and $\mathrm{P}=3.4 \mathrm{MPa}$. As for the target reaction Gibbs energy is equal to $-43.4 \mathrm{~kJ} / \mathrm{mol}$ and according to all defined $\Delta G$ of the considered reactions, thermodynamic possibility of these reactions is probable. The determination was performed with the use of Gaussian-98 program by PM3 semi-empirical method.

The graphical description of the reactions pathway of benzene alkylation is shown in Figure 1. Among them there are benzene alkylation of ethylene and propylene (ethylene feed impurity), toluene (benzene feed impurity) alkylation, next step of alkylation caused by the PEB formation, heavy by-product formation (diphenylethane) through the intermediate formation in the process of incomplete benzene alkylation.

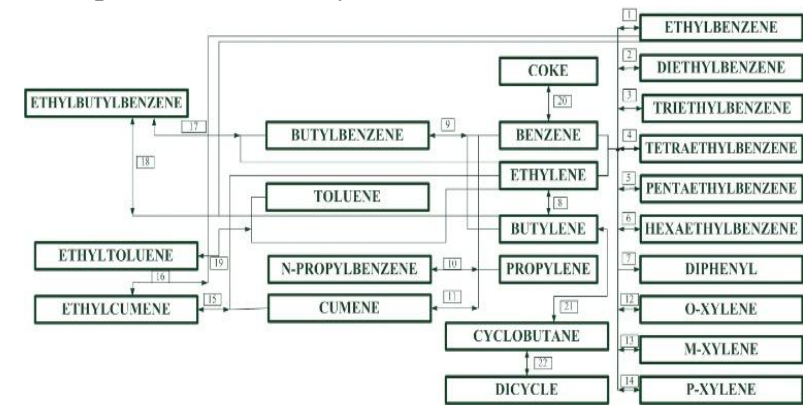

Figure 1. Detailed scheme of hydrocarbons conversion in the process of alkylation of benzene with ethylene

The scheme needs to be formalized (simplified) in order it could be used for future computations; at the same time it is to provide the highly accurate description of the process.
Formalization was performed by means of uniting individual substances into the pseudo-components having similar reactivity in respect of a particular reaction. The determination of compensation degree, which is characterized by the partial compensation of the energy expended on the breaking of the old bonds by the energy of the new bonds formation on the reaction route, was considerably helpful in solving the problems of catalytic action prediction.

Therefore, further step is to study the degree of compensation for the list of considered reactions.

$$
H=\frac{\sum D_{i}-E_{a}}{\sum D_{i}} \cdot 100 \%
$$

where $\sum D_{i}$ - the energy of bounds breaking, $\mathrm{kJ} / \mathrm{mol}$, $E_{a}$ - energy of activation, $\mathrm{kJ} / \mathrm{mol}$.

The main problem in calculation of the compensation energy is to determine the activation energy of the reaction.

As the first approximation, the activation energy was calculated according to Polanyi-Semenov equation for exothermic reactions [14].

$$
E_{a}=11.5+0.25 \cdot \Delta H
$$

where $E_{a}$ - energy of activation, kcal / mol, $\Delta H$ - heat of reaction, $\mathrm{kcal} / \mathrm{mol}$.

Enthalpy of the reactions was calculated with the use of quantum-chemical methods of thermodynamic functions determination. The calculated enthalpy of alkylation reaction of benzene with ethylene $(-117.9 \mathrm{~kJ} /$ mol) was compared with the literature data $(-113 \mathrm{~kJ} / \mathrm{mol})$ [15] as a proof of the relevance of the method for the unknown enthalpy of some reactions in the literature. All the considered reactions are exothermic.

Then the activation energy of the given reaction was calculated in first approximation with the use of the empiric equation. The value of the reaction mentioned above is $78.5 \mathrm{~kJ} / \mathrm{mol}$ in comparison with $63.4 \mathrm{~kJ} / \mathrm{mol}$ in [16]. It's important to note that activation energy that was found for all reaction refers to the non-catalytic process, and it was good for the first approximation on next stage of the parameter estimation. The meanings of defined activation energy according to Polanyi-Semenov equation at $\mathrm{T}=510^{\circ} \mathrm{K}$ and $\mathrm{P}=3.4 \mathrm{MPa}$ are represented in Table 1. However, it might be improved with the use of literature sources of activation energy values for some reactions. After that the activation energy could be calibrated to the activation energy of the reaction.

The next step in calculating the degree of compensation is the determination of the energy of bonds breaking. Let's consider the methods based on the example of the above-mentioned reaction.

To form ethylbenzene it's necessary to break the two bonds: $\mathrm{C}-\mathrm{H}$ bond in a molecule of benzene and $\mathrm{C}-\mathrm{H}$ bond in a molecule of ethylene. The energies of these bonds have been calculated with the use of Gaussian-98.

The energy of the first bond was $433.8 \mathrm{~kJ} / \mathrm{mol}$, the energy of the second one was $215.5 \mathrm{~kJ} / \mathrm{mol}$. The energy of bonds breaking was equal to $649.3 \mathrm{~kJ} / \mathrm{mol}$. Similarly, the energy of bonds breaking was calculated for the rest 
of the reactions, and then the degree of compensation was calculated by the formula (1). The results are shown in Table 1. The literature values of the energy of bonds breaking and their comparison with the determined values are also shown in Table 1.

Table 1. Results of determined degrees of reaction compensation

\begin{tabular}{|c|c|c|c|c|c|}
\hline Reaction & $\begin{array}{c}E_{a} \\
\text { (Polanyi- } \\
\text { Semenov } \\
\text { ), kJ / } \\
\text { mol }\end{array}$ & \begin{tabular}{|c|}
$\sum D_{i}$, \\
$\mathbf{k J} /$ \\
$\mathbf{m o l}$
\end{tabular} & $\begin{array}{c}\sum D_{i} \\
\mathbf{k J} / \mathbf{m o l} \\
\text { (literature } \\
\text { ) }\end{array}$ & $\Delta \sum_{\%} D_{i}$ & $\begin{array}{l}H, \\
\%\end{array}$ \\
\hline $\begin{array}{c}\text { Benzene }+ \\
\text { Ethylene }= \\
\text { Ethylbenzene }\end{array}$ & 78.5 & 649.3 & 715.0 & 9.2 & 90.2 \\
\hline $\begin{array}{l}\text { Ethylbenzene }+ \\
\text { Ethylene = } \\
\text { Diethylbenzene }\end{array}$ & 86.1 & 633.5 & 715.0 & 11.4 & 92.6 \\
\hline $\begin{array}{c}\text { Diethylbenzene }+ \\
\text { Ethylene = } \\
\text { Triethylbenzene }\end{array}$ & 90.7 & 617.7 & 715.0 & 13.6 & 88.9 \\
\hline $\begin{array}{l}\text { Triethylbenzene }+ \\
\text { Ethylene }= \\
\text { Tetraethylbenzene }\end{array}$ & 84.4 & 602.0 & 715.0 & 15.8 & 89.1 \\
\hline $\begin{array}{l}\text { Tetraethylbenzene } \\
+ \text { Ethylene }= \\
\text { Pentaethylbenzene }\end{array}$ & 84.8 & 586.2 & 715.0 & 18.0 & 88.8 \\
\hline $\begin{array}{l}\text { Pentaethylbenzene } \\
+ \text { Ethylene }= \\
\text { Hexaethylbenzene }\end{array}$ & 93.2 & 570.4 & 715.0 & 20.2 & 87.9 \\
\hline $\begin{array}{c}\text { 2Benzene }+ \\
\text { Ethylene }= \\
\text { Diphenylethane }+ \\
\text { Hydrogen }\end{array}$ & 94.1 & 1083.2 & 1100.0 & 1.5 & 93.6 \\
\hline $\begin{array}{c}\text { Ethylene }+ \\
\text { Ethylene }= \\
\text { Butylene }\end{array}$ & 77.7 & 882.2 & 955.0 & 7.6 & 92.8 \\
\hline $\begin{array}{c}\text { Benzene }+ \\
\text { Butylene }= \\
\text { Butylbenzene }\end{array}$ & 105.8 & 762.9 & 685.0 & 11.4 & 90.3 \\
\hline $\begin{array}{c}\text { Benzene }+ \\
\text { Propylene }=\mathrm{n}- \\
\text { Propylbenzene }\end{array}$ & 99.1 & 788.2 & 685.0 & 15.1 & 90.9 \\
\hline $\begin{array}{c}\text { Benzene }+ \\
\text { Propylene }= \\
\text { Cumene }\end{array}$ & 107.9 & 788.2 & 685.0 & 15.1 & 90.5 \\
\hline $\begin{array}{c}\text { Benzene }+ \\
\text { Ethylene = o- } \\
\text { Xylene }\end{array}$ & 63.8 & 1298.7 & 1428.0 & 9.1 & 95.6 \\
\hline $\begin{array}{c}\text { Benzene }+ \\
\text { Ethylene }=\text { m- } \\
\text { Xylene }\end{array}$ & 55.0 & 1298.7 & 1428.0 & 9.1 & 95.8 \\
\hline $\begin{array}{c}\text { Benzene }+ \\
\text { Ethylene }=\text { p- } \\
\text { Xylene }\end{array}$ & 55.0 & 1298.7 & 1428.0 & 9.1 & 95.8 \\
\hline $\begin{array}{c}\text { Cumene }+ \\
\text { Ethylene }= \\
\text { Ethylcumene }\end{array}$ & 94.5 & 633.0 & 715.0 & 11.5 & 89.0 \\
\hline $\begin{array}{l}\text { Ethylbenzene }+ \\
\text { Propylene }= \\
\text { Ethylcumene }\end{array}$ & 123.5 & 772.3 & 715.0 & 8.0 & 89.5 \\
\hline $\begin{array}{c}\text { Butylbenzene + } \\
\text { Ethylene = } \\
\text { Ethylbutylbenzene }\end{array}$ & 92.8 & 635.4 & 715.0 & 11.1 & 89.1 \\
\hline Ethylbenzene + & 120.5 & \begin{tabular}{|l|l|}
747.1 \\
\end{tabular} & 715.0 & 4.5 & 89.3 \\
\hline
\end{tabular}

\begin{tabular}{|c|c|c|c|c|c|}
\hline $\begin{array}{c}\text { Butylene }= \\
\text { Ethylbutylbenzene }\end{array}$ & & & & & \\
\hline $\begin{array}{c}\text { Toluene }+ \\
\text { Ethylene }= \\
\text { Ethyltoluene }\end{array}$ & 108.4 & 747.6 & 715.0 & 4.6 & 89.9 \\
\hline $\begin{array}{c}\text { 6Benzene }= \\
\text { Coronene }+ \\
\text { Hydrogen }\end{array}$ & $\begin{array}{c}1179 . \\
8\end{array}$ & 5206.0 & 4980.0 & 4.5 & 90.3 \\
\hline $\begin{array}{c}\text { Butylene }=\text { cis- } \\
\text { Butene }\end{array}$ & 183.1 & 952.5 & 1014.0 & 6.1 & 89.0 \\
\hline $\begin{array}{c}\text { cis-Butene }+ \text { cis- } \\
\text { Butene }= \\
\text { Dicyclobutane }+ \\
\text { Hydrogen }\end{array}$ & 166.3 & 809.6 & 830.0 & 2.5 & 87.8 \\
\hline
\end{tabular}

Computation results show the good comparability of the determined values of energy of bonds breaking with the literature data.

\section{Results and discussions}

In order to formalize the transformation schemes, reactions were divided into two groups by the criterion of the similarity of their values of compensation degree (Table 2). The degree of compensation for the same group of reactions differs approximately by $1 \%$ [17-19].

Table 2. Alkylation reactions grouping by their degrees of compensation

\begin{tabular}{|c|c|}
\hline Reaction group & $\begin{array}{c}\text { Average } H, \% \\
\text { for reaction } \\
\text { group }\end{array}$ \\
\hline 1. Ethylbenzene formation & 90.2 \\
\hline \multicolumn{2}{|l|}{ Benzene + Ethylene $=$ Ethylbenzene } \\
\hline 2. Diethylbenzene formation & 92.6 \\
\hline \multicolumn{2}{|l|}{$\begin{array}{l}\text { Ethylbenzene }+ \text { Ethylene }= \\
\text { Diethylbenzene }\end{array}$} \\
\hline 3. Triethylbenzene formation & 88.9 \\
\hline \multicolumn{2}{|l|}{$\begin{array}{l}\text { Diethylbenzene }+ \text { Ethylene }= \\
\text { Triethylenebenzene }\end{array}$} \\
\hline 4. Heavy compounds formation & 89.8 \\
\hline \multicolumn{2}{|l|}{$\begin{array}{l}\text { Triethylbenzene }+ \text { Ethylene }= \\
\text { Polyethylenebenzene }\end{array}$} \\
\hline \multicolumn{2}{|l|}{$\begin{array}{c}\text { 2Benzene }+ \text { Ethylene }=\text { Diphenylethane }+ \\
\text { Hydrogen }\end{array}$} \\
\hline 5. Other monoalkylates formation & 90.6 \\
\hline \multicolumn{2}{|l|}{ Benzene + Butylene $=$ Monoalkylate } \\
\hline \multicolumn{2}{|l|}{ Benzene + Propylene $=$ Monoalkylate } \\
\hline 6. Xylene formation & 95.7 \\
\hline \multicolumn{2}{|l|}{ Benzene + Ethylene $=$ Xylene } \\
\hline 7. Other dialkylates formation & 89.4 \\
\hline \multicolumn{2}{|l|}{ Ethylbenzene + Propylene $=$ Dialkylate } \\
\hline \multicolumn{2}{|l|}{ Ethylbenzene + Butylene $=$ Dialkylate } \\
\hline \multicolumn{2}{|l|}{ Monoalkylate + Ethylene $=$ Dialkylate } \\
\hline \multicolumn{2}{|l|}{ Toluene + Ethylene $=$ Dialkylate } \\
\hline 8. Coke formation & 90.3 \\
\hline \multicolumn{2}{|l|}{ 6Benzene $=$ Coke + Hydrogen } \\
\hline 9. Cyclo and dicyclo formation & 88.4 \\
\hline \multicolumn{2}{|l|}{ Butylene $=$ cis-Butene } \\
\hline \multicolumn{2}{|l|}{$\begin{array}{c}\text { cis-Butene }+ \text { cis-Butene }=\text { Dicyclobutane } \\
+ \text { Hydrogen }\end{array}$} \\
\hline 10. Butylene formation & 92.8 \\
\hline Ethylene + Ethylene $=$ Butylene & \\
\hline
\end{tabular}


Thus, it is possible to identify the number of pseudocomponents: the heavy compounds which are composed of individual components such as tetra-, penta-, hexaethylbenzene and diphenylethane; monoalkylates (butylbenzene, n-propylbenzene, cumene), dialkylates (ethylcumene, ethylbutylbenzene), xylenes (o-, m-, pxylene), cyclic and dicyclic hydrocarbons. Formalized scheme of hydrocarbons transformations is shown in Figure 2.

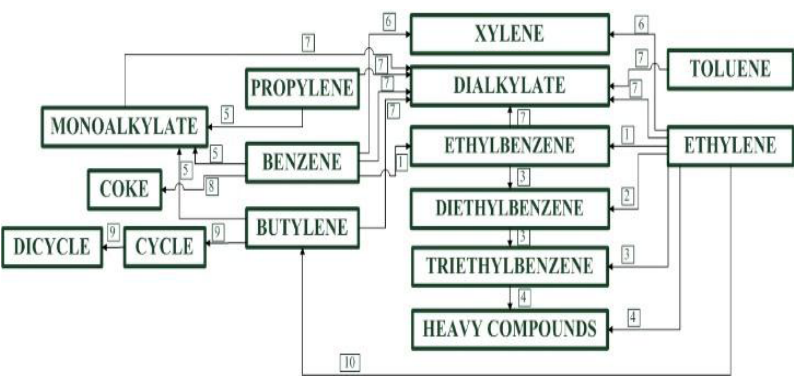

Figure 2. Formalized scheme of hydrocarbons transformations in benzene in process of its alkylation with ethylene

According to the law of mass action the expressions of the rates of alkylation and transalkylation reactions can be put as follows (Table 3).

Table 3. Reaction rate expressions in alkylation and transalkylation

\begin{tabular}{|c|c|}
\hline Reaction group & Reaction rate expression \\
\hline $\begin{array}{l}\text { 1. Ethylbenzene } \\
\text { formation }\end{array}$ & $W_{1}=k_{0(1)} \cdot e^{-E a(1) / R T} \cdot C_{\text {benzene }} \cdot C_{\text {ethylene }}$ \\
\hline $\begin{array}{l}\text { 2. Diethylbenzene } \\
\text { formation }\end{array}$ & $W_{2}=k_{0(2)} \cdot e^{-E a(2) / R T} \cdot C_{\text {ethylbenzene }} \cdot C_{\text {ethylene }}$ \\
\hline $\begin{array}{l}\text { 3. Triethylbenzene } \\
\text { formation }\end{array}$ & $W_{3}=k_{0(3)} \cdot e^{-E a(3) / R T} \cdot C_{\text {diethylbenzene }} \cdot C_{\text {ethylene }}$ \\
\hline $\begin{array}{l}\text { 4. Heavy } \\
\text { compounds } \\
\text { formation }\end{array}$ & $\begin{array}{l}W_{4.1}=k_{0(4)} \cdot e^{-E a(4.1) / R T} \cdot C_{\text {triethylbenzene }} \cdot C_{\text {ethylene }} \\
W_{4.2}=k_{0(4)} \cdot e^{-E a(4.2) / R T} \cdot C_{\text {benzene }}^{2} \cdot C_{\text {ethylene }}\end{array}$ \\
\hline $\begin{array}{l}\text { 5. Other } \\
\text { monoalkylates } \\
\text { formation }\end{array}$ & $\begin{array}{l}W_{5.1}=k_{0(5)} \cdot e^{-E a(5.1) / R T} \cdot C_{\text {benzene }} \cdot C_{\text {butylene }} \\
W_{5.2}=k_{0(5)} \cdot e^{-E a(5.2) / R T} \cdot C_{\text {benzene }} \cdot C_{\text {propylene }}\end{array}$ \\
\hline $\begin{array}{l}\text { 6. Xylene } \\
\text { formation }\end{array}$ & $W_{6}=k_{0(6)} \cdot e^{-E a(6) / R T} \cdot C_{\text {benzene }} \cdot C_{\text {ethylene }}$ \\
\hline $\begin{array}{l}\text { 7. Other } \\
\text { dialkylates } \\
\text { formation }\end{array}$ & $\begin{array}{l}W_{7.1}=k_{0(7)} \cdot e^{-E a(7.1) / R T} \cdot C_{\text {ethylbenzene }} \cdot C_{\text {propylene }} \\
W_{7.2}=k_{0(7)} \cdot e^{-E a(7.2) / R T} \cdot C_{\text {ethylbenzene }} \cdot C_{\text {butylene }} \\
W_{7.3}=k_{0(7)} \cdot e^{-E a(7.3) / R T} \cdot C_{\text {monoalkylate }} \cdot C_{\text {ethylene }} \\
W_{7.4}=k_{0(7)} \cdot e^{-E a(7.4) / R T} \cdot C_{\text {toluene }} \cdot C_{\text {ethylene }}\end{array}$ \\
\hline $\begin{array}{l}\text { 8. Coke } \\
\text { formation }\end{array}$ & $W_{8}=k_{0(8)} \cdot e^{-E a(8) / R T} \cdot C_{\text {benzene }}^{6}$ \\
\hline $\begin{array}{l}\text { 9. Cyclo and } \\
\text { dicyclo } \\
\text { formation }\end{array}$ & $\begin{array}{c}W_{9.1}=k_{0(9)} \cdot e^{-E a(9.1) / R T} \cdot C_{\text {butylene }} \\
W_{9.2}=k_{0(9)} \cdot e^{-E a(9.2) / R T} \cdot C_{\text {cis-butene }}^{2}\end{array}$ \\
\hline $\begin{array}{l}\text { 10. Butylene } \\
\text { formation }\end{array}$ & $W_{10}=k_{0(10)} \cdot e^{-E a\left(_{10}\right) / R T} \cdot C_{\text {ethylene }}^{2}$ \\
\hline
\end{tabular}

where $W_{i}$ - rate of $i$ - group reaction; $k_{0(i)}$ - preexponential factor for $i$ - group reaction; $E a_{(i, j)}-$ activation energy of $j$ - subgroup for $i$ - group reaction.
Similar work was carried out with the transalkylation process. Kinetic models of alkylation and transalkylation are presented in Table 4.

Table 4. Kinetic models of alkylation and transalkylation

\begin{tabular}{|c|c|}
\hline $\begin{array}{c}\text { The kinetic model of } \\
\text { alkylation }\end{array}$ & $\begin{array}{l}\text { The kinetic model of } \\
\text { transalkylation }\end{array}$ \\
\hline 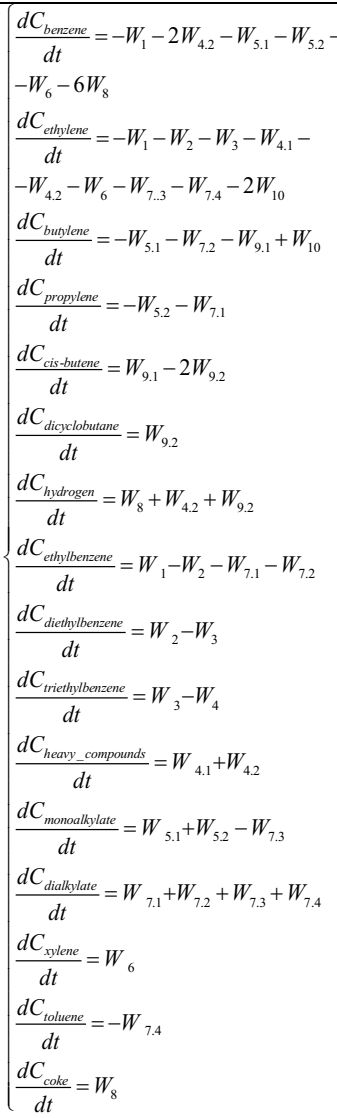 & 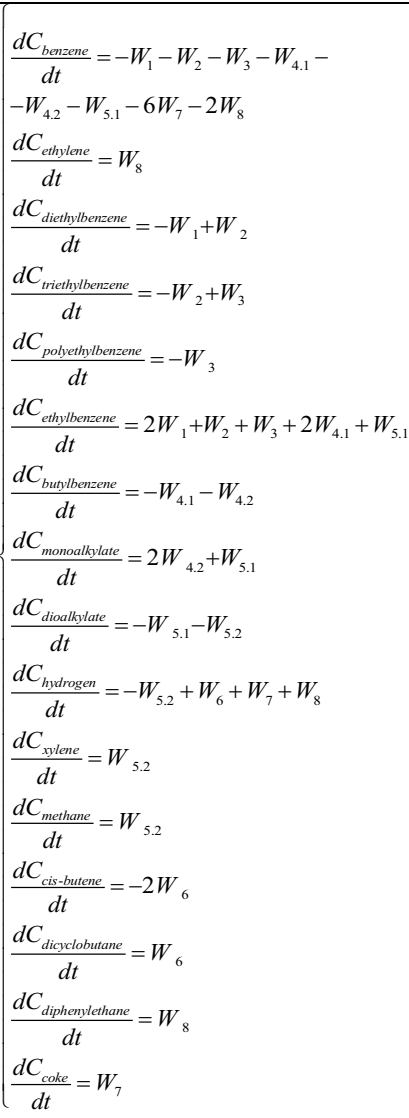 \\
\hline
\end{tabular}

Initial conditions are: $t=0, \quad C_{i}=\mathrm{C}_{0 i}$, where $i-$ corresponding hydrocarbon.

The kinetic models presented in the paper are to become the basis for the computer simulation of the ethylbenzene production system development.

\section{Conclusion}

Thermodynamic analysis of alkylation and transalkylation reactions were performed with the use of quantum-chemical methods of calculating thermodynamic functions. The method of formalization of the hydrocarbons transformation scheme, which consists in the grouping of components by their reactivity drawing on the compensation degree values of the corresponding reactions, was developed. The correctness of the determination of the energy of bonds breaking in the reagent's molecules is confirmed by comparison of its results with the literature data. The kinetic models of alkylation of benzene with ethylene and polialkylbenzenes transalkylation were developed on the basis of the formalized transformations schemes. 


\section{References}

1. Thomas F. Degnan Jr, C Morris Smith, Chaya R, Venkat, Appl. Catal. A: Gen. J. 221, 283-294 (2001)

2. C.Perego, P. Ingallina, Catal. Today, 73, 3-22 (2002)

3. Jennifer Carvajal-Diaz, David Byrne CEH (2015)

4. Robert A. Meyers, Handbook of Heterogeneous Catalysis, McGRAW-HILL, USA, 665 (2005)

5. N. Ebrahimi Ali, Z. Sharak Ashkan, A. Mousavi Seyyed, Faeze Aghazadeh, Ahmad Soltani, Chemical Engineering and Processing, 50, 31-36 (2011)

6. Xiaoming Chen, Shiping Huang, Dapeng Cao Fluid.Ph.Equilibria, 260, 146-152 (2007)

7. V.A. Fetisova, E.D. Ivashkina, E.N., Ivanchina, A.V. Kravtsov, Catal. In Industry 2-1, 55-61 (2010)

8. T.Odedairo, S. Al-Khattaf, Chemical Engineering J. 167, 240-254 (2011)

9. Evgeniya Frantsina, Elena Ivashkina, Emiliya Ivanchina, Rostislav Romanovskii, Chemical Engineering Journal (available online 28 February 2015)

10. L. Forni, G. Cremona, F. Missineo, G. Bellusi, C. Perego, G. Pazzuconi, App. Cat. A:General J. 121, 261-272 (1995)
11. F. Canavi, MCorazzari, E. Bencini, G.Goffredi, App. Cat. A:General J. 226, 31-40 (2004)

12. Tseng-Chang Tsai, Shang-Bin Liu, Ikai Wang, App. Cat. A:General J. 181, 355-398 (1999)

13. N. Hamendi, D. Iranshahi, M.R. Rahimpour, S. Raeissi, H. Rajaei, Journal of the Taiwan Inst. Of Chem. Eng J. 48, 56-72 (2015)

14. Anthony G. Dixon, Advances in Chemical Engineering, USA, 301 (2014)

15. Kgutso Mokaema Alkyl-Transfer (Transalkylation) reactions of alkylaromatics on solid acid catalyst, Johannesburg, 68 (2005)

16. Hamid Ganji, Jafar S, Ahari et all, Petroleum\&Coal J. 46, 1, 55-63 (2004)

17. Howard F. Rase, Handbook of Commercial Catalyst. Heterogeneous Catalyst, CRC Press, USA, 551 (2000)

18. Nurmakanova A. E., Salishcheva A. A., Chudinova A. A., Syskina A. A., Ivashkina Procedia Chemistry, 10, 284-288 (2014)

19. Khlebnikova E. S., Bekker A. V., Ivashkina E. N., Procedia Chemistry, 10, 297-304 (2014) 